\title{
Rechtstoerisme: Burgerlijk Wetboek en Grondwet voorbij de Staat
}

Citation for published version (APA):

Smits, J. M. (2010). Rechtstoerisme: Burgerlijk Wetboek en Grondwet voorbij de Staat. Tilburg University Press. https://doi.org/10.26481/spe.20100205js

Document status and date:

Published: 05/02/2010

DOI:

$10.26481 /$ spe.20100205js

Document Version:

Publisher's PDF, also known as Version of record

\section{Please check the document version of this publication:}

- A submitted manuscript is the version of the article upon submission and before peer-review. There can be important differences between the submitted version and the official published version of record.

People interested in the research are advised to contact the author for the final version of the publication, or visit the DOI to the publisher's website.

- The final author version and the galley proof are versions of the publication after peer review.

- The final published version features the final layout of the paper including the volume, issue and page numbers.

Link to publication

\footnotetext{
General rights rights.

- You may freely distribute the URL identifying the publication in the public portal. please follow below link for the End User Agreement:

www.umlib.nl/taverne-license

Take down policy

If you believe that this document breaches copyright please contact us at:

repository@maastrichtuniversity.nl

providing details and we will investigate your claim.
}

Copyright and moral rights for the publications made accessible in the public portal are retained by the authors and/or other copyright owners and it is a condition of accessing publications that users recognise and abide by the legal requirements associated with these

- Users may download and print one copy of any publication from the public portal for the purpose of private study or research.

- You may not further distribute the material or use it for any profit-making activity or commercial gain

If the publication is distributed under the terms of Article $25 \mathrm{fa}$ of the Dutch Copyright Act, indicated by the "Taverne" license above, 


\section{RECHTSTOERISME:}

REDE, UITGESPROKEN DOOR JAN SMITS

BURGERLIJK WETBOEK

EN GRONDWET VOORBIJ

DE STAAT

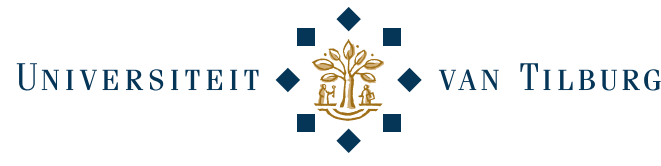


Jan.M. Smits is hoogleraar Europees privaatrecht en rechtsvergelijking aan de Universiteit van Tilburg en wetenschappelijk directeur van het Tilburg Institute of Comparative and Transnational Law (TICOM). Van 1999 tot 2008 was hij hoogleraar Europees privaatrecht aan de Universiteit Maastricht. Hij is tevens gasthoogleraar Comparative Legal Studies aan de Universiteit van Helsinki en was eerder gasthoogleraar aan onder meer de universiteiten van Leuven en Luik en aan de Dickinson School of Law. Zie voor meer informatie over Smits en zijn wetenschappelijk werk <http://www.jansmits.eu>

Een uitgebreide wetenschappelijke Engelstalige versie van deze rede verschijnt in 2010.

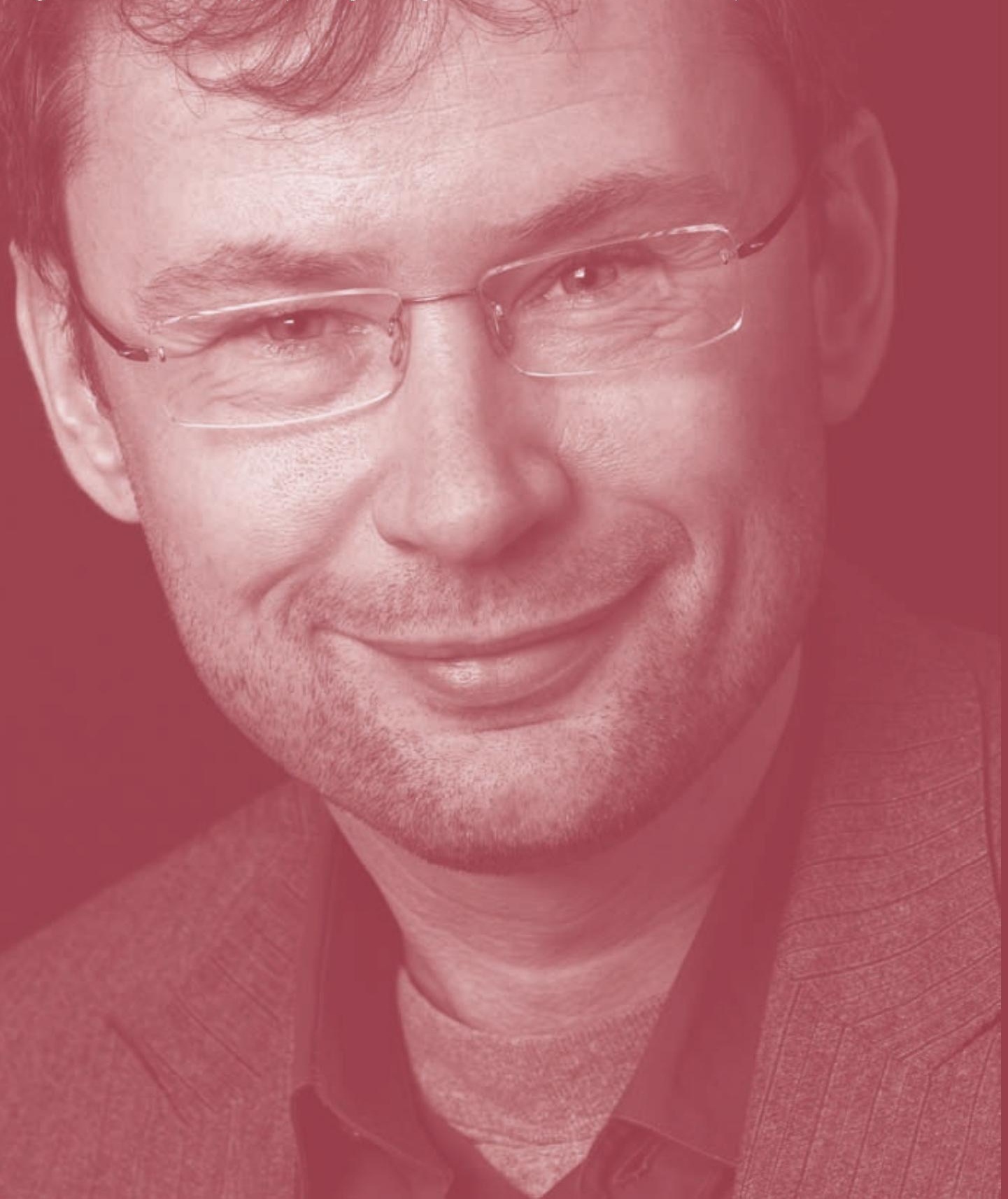




\section{RECHTSTOERISME: BURGERLIJK WETBOEK EN GRONDWET VOORBIJ DE STAAT}

Nederlandse vertaling van de rede, in het Engels uitgesproken bij de openbare aanvaarding van het ambt van hoogleraar in het Europees privaatrecht en de rechtsvergelijking aan de Universiteit van Tilburg op 5 februari 2010, door Jan Smits 
(C) Universiteit van Tilburg, 2010

ISBN: 978-90-78886-64-8

Alle rechten voorbehouden. Niets uit deze uitgave mag worden verveelvoudigd, opgeslagen in een

geautomatiseerd gegevensbestand, of openbaar gemaakt, in enige vorm of op enige wijze, hetzij elektronisch, mechanisch, door fotokopieën, opnamen of op enige andere manier.

www.uvt.nl 


\section{Mijnheer de Rector Magnificus, Mijnheer de Decaan van de Faculteit Rechtswetenschappen, Zeer gewaardeerde studenten, collega's, familie en vrienden.}

\section{Proloog Bij aanvang van deze inaugurele rede wil ik u graag uitnodigen voor een}

kleine reis. De reis begint in Tilburg, alwaar wij niet ver van het Centraal Station kantoorgebouw Het Laken aantreffen. Op de vierde verdieping van dit gebouw bevindt zich het kantoor van een kleine Nederlandse onderneming die handelt in elektronische producten. In de vergaderzaal vinden onderhandelingen plaats tussen de directeur van het bedrijf en twee vertegenwoordigers van een andere onderneming. Deze andere onderneming is gevestigd in Griekenland. Ik kan onthullen dat de onderhandelingen binnen enkele uren zullen hebben geleid tot overeenstemming tussen partijen. Ik ben ook verheugd om $u$ te kunnen melden dat het Nederlandse en het Griekse bedrijf gaan besluiten om niet hun eigen (Nederlandse of Griekse) recht op de overeenkomst van toepassing te verklaren, maar zullen opteren voor Duits recht. Zij doen dat door in hun overeenkomst een bepaling op te nemen die luidt: 'German substantive law shall apply to this Agreement.'

Met deze kennis over wat zich de komende uren in Tilburg zal afspelen, kunnen we onze reis nu gerust voortzetten naar andere oorden. Voor de volgende etappe nemen we in Tilburg de trein naar Schiphol. Vanaf daar vliegen we naar Montréal. Morgen zullen we in het stadhuis van Montréal getuige zijn van een huwelijk. Dit huwelijk gaat worden gesloten tussen twee Fransen van hetzelfde geslacht. Opmerkelijk genoeg reisden deze twee mannen of vrouwen helemaal vanuit Europa naar Québec om te trouwen. Zij voelden zich daartoe genoodzaakt omdat, hoewel thans vijf Europese landen het homohuwelijk erkennen (waaronder Nederland en België), deze landen niet toestaan dat buitenlanders of niet-inwoners op hun grondgebied trouwen. Twee Fransen of Duitsers (ongeacht hun seksuele voorkeur) kunnen niet huwen in Tilburg of in enige andere Nederlandse stad tenzij op zijn minst één van hen hier woont. Gelukkig voor onze twee Fransen erkent Québec, net als andere Canadese provincies, het homohuwelijk sinds 2004 en staat het ook niet-Canadezen toe om in Canada te trouwen.

Onze reis nadert reeds zijn einde. Morgenavond, terwijl ons echtpaar nog feest viert, zijn wij alweer onderweg naar Europa. We landen in Brussel en rijden van daar met de auto naar de fascinerende stad Luik. In Luik ontmoeten we Igor de Camargo, stervoetballer van de Belgische nationale kampioen Royal Standard de Liège. Hoewel Igor is geboren in Brazilië en ook de Braziliaanse nationaliteit heeft, is hij sinds één jaar ook Belgisch staatsburger. Hij werd Belg om deel te kunnen nemen aan internationale voetbaltoernooien, zoals het Wereldkampioenschap en het Europees Kampioenschap. Igors kwaliteiten als voetballer zijn weliswaar groot, maar niet groot genoeg om uit te kunnen 
komen voor het Braziliaanse elftal. Nu hij Belg is, kan hij wel spelen voor België - hetgeen hij ook al diverse malen deed. Enkelen van u zullen zich herinneren dat dit voor sporters een niet ongebruikelijke strategie is. Zo werd ook de bekende Nederlandse schaatser Bart Veldkamp in 1996 Belg om zo mee te kunnen doen aan internationale toernooien toen hij niet langer werd geselecteerd voor het Nederlandse team. Veldkamp wordt sindsdien wel aangeduid met de term 'Schaatsbelg.' Tegenwoordig bestaan kennelijk ook 'Voetbalbelgen' en zijn er zelfs 'Schaatskazachen' en een enkele 'Paardenbelg' gesignaleerd.

\section{Drie gevallen,}

één gedachte Eén van de beroemdste rechtsgeleerden in de geschiedenis, de Duitser Rudolf Von Jhering, signaleerde nu meer dan 150 jaar geleden dat de rechtswetenschap was verworden tot een nationale, en daarmee bekrompen, discipline. Die situatie, door Von Jhering terecht beschouwd als een wetenschap onwaardig, is de laatste twee decennia ten goede gekeerd: de juridische discipline heeft een enorme internationalisering ondergaan. Geheel nieuwe rechtsterreinen van Europees privaatrecht, Europees constitutioneel recht en Europees strafrecht zijn opgekomen als gevolg van de sterk toegenomen hoeveelheid met gezag beklede teksten die worden afgescheiden door de Europese wetgever en rechters. Deze Europeanisering is echter niet de enige vorm van internationalisering die zich heeft voorgedaan. Daarnaast is er een ander type internationalisering dat veel minder in het oog springt, maar waarvan de invloed minstens even ingrijpend is als die van de meer zichtbare activiteiten van de Europese instituties. In deze rede wil ik graag uw aandacht vragen voor dit andere verschijnsel, dat kan worden omschreven als een ontwikkeling naar recht voorbij de nationale Staat. De drie voorbeelden die ik zojuist gaf - en die gemakkelijk kunnen worden uitgebreid met andere - zijn illustratief voor deze ontwikkeling.

Laat ons daarom nu eerst terugkeren naar deze voorbeelden en ons afvragen wat het is dat zij gemeen hebben. Kortweg is dit dat, op drie verschillende terreinen van het maatschappelijk leven, personen een keuze maken voor een andere jurisdictie dan die van hen zelf. De contractspartijen, de homoseksuelen en de voetballer zijn geen van allen tevreden met hun eigen rechtsstelsel omdat het hen niet in staat stelt iets te doen dat zij wel willen. Daarom kiezen zij, steeds voor een bepaald aspect van hun bedrijf, hun persoonlijke leven of hun beroep, voor een andere jurisdictie. Laat ik dit voor elk van de genoemde voorbeelden kort toelichten.

Het eerste voorbeeld is voor juristen zeer bekend. In het contractenrecht bestaan uitgebreide mogelijkheden voor rechtskeuze: gedreven door een veelheid aan motieven kunnen partijen besluiten om een ander recht van toepassing te verklaren dan dat van 
hun 'eigen' Staat in elke verhouding met enig internationaal aspect (zoals dat partijen elk uit een ander land komen). En dit is zelfs mogelijk zonder dat partijen daarvoor hoeven te reizen: zij blijven in eigen land en kiezen voor een buitenlands contractenrecht met een enkele pennenstreek. Voor commerciële partijen is dit een populaire strategie: uit empirisch onderzoek blijkt dat in Europa meer dan vier op de tien bedrijven op zijn minst af en toe kiest voor een vreemd rechtsstelsel.

In het tweede voorbeeld zijn het niet twee contractspartijen die een overeenkomst wensen te sluiten, maar twee geliefden die met elkaar willen huwen. Hun eigen recht staat dit niet toe en daarom besluiten zij om te profiteren van een buitenlands rechtsstelsel. Een groot verschil met het eerste geval is dat partijen nu wél moeten reizen en zich moeten vervoegen bij de huwelijksambtenaar van de buitenlandse stad van hun voorkeur. Maar zodra zij dat hebben gedaan, keren ze terug naar huis als een getrouwd stel. Zelfs als hun woonland dit huwelijk niet erkent (of niet alle aspecten er van) is het enkele feit dat zij in staat waren te trouwen voor hen nog altijd symbolisch belangrijk. Dit huwelijkstoerisme heeft recent een hoge vlucht genomen. Zo is Canada één van de plaatsen waar buitenlanders een homohuwelijk kunnen sluiten zonder daar daadwerkelijk te wonen. Cijfers van Statistics Canada laten zien dat meer dan de helft van de daar afgesloten huwelijken tussen partners van gelijk geslacht plaatsvindt tussen personen die niet in Canada wonen. Deze trouwlustigen komen tot nu toe grotendeels uit de Verenigde Staten en Europa.

Voor wie een juridische opleiding heeft genoten lijkt het derde voorbeeld op geheel ander terrein te liggen. Toch gaat het ook hier om een geval waarin personen ontevreden zijn over een bepaald aspect van hun eigen jurisdictie. Dat is zelfs in die mate het geval dat zij de vergaande stap zetten om te kiezen voor een andere nationaliteit om deel te kunnen nemen aan een sporttoernooi. En kennelijk zijn bepaalde Staten bereid om hen te helpen. Het behoeft weinig betoog dat dit ook in het belang is van deze Staten zelf. Recent gaven nog twee andere Braziliaanse spelers aan graag in Igor de Camargo's voetsporen te willen treden en te zullen opteren voor het Belgisch staatsburgerschap. Het is één van de weinige dingen waar Dick Advocaat niet over klaagde toen hij bondscoach van België werd. Ook andere landen zijn vaak bereid om sporters in te lijven. Belangrijk is om zich te realiseren dat ook hier personen enkel geïnteresseerd zijn in één enkel aspect van een buitenlands rechtsstelsel, in dit geval de mogelijkheid deel te kunnen nemen aan een sporttoernooi. Voor alle andere aspecten van hun leven prefereren zij waarschijnlijk hun oorspronkelijke nationaliteit (zoals Bart Veldkamp gewoon in zijn geboorteplaats Den Haag bleef wonen toen hij voor België uitkwam). 
De rechtsmarkt Tot nu toe heb ik getracht om duidelijk te maken dat mensen niet altijd tevreden zijn met hun eigen rechtsstelsel en daarom besluiten om (al dan niet fysiek) hun land te verlaten: zij kiezen een andere jurisdictie voor een bepaald aspect van hun leven omdat zij menen dat hun behoeften daarmee beter worden bevredigd. Dit fenomeen staat thans sterk in de belangstelling.' Het werd recent omschreven als een 'rechtsmarkt': zoals een consument iets koopt in de supermarkt, kan hij ook het recht van zijn voorkeur inkopen. Het betekent dat recht, op die terreinen waar een dergelijke rechtsmarkt daadwerkelijk bestaat, tot een product geworden is. Voor wie dat niet gelooft, zet ik mijn betoog kracht bij met behulp van enkele recente documenten.

Het eerste document is een brochure die is uitgegeven door The Law Society of England and Wales, ${ }^{2}$ de invloedrijke beroepsorganisatie van Engelse advocaten. De brochure bevat niets meer of minder dan propaganda voor het Engelse rechtssysteem. De tekst tracht buitenlandse commerciële partijen te verleiden om Engels recht als het toepasselijke recht te kiezen en Londen als de plaats van arbitrage. De brochure noemt diverse redenen waarom Engels recht valt te prefereren en eindigt met de uitsmijter dat 'English law is more flexible than many civil law systems.' Het tweede document is uitgegeven door de Duitse Minister van Justitie. Na kennis te hebben genomen van de Engelse brochure meende de Duitse regering kennelijk niet achter te kunnen blijven en publiceerde een folder met als titel 'Law - Made in Germany: global, effective and cost-efficient.' deze brochure tracht om (dit maal) Duits recht aan te prijzen als het beste rechtsstelsel ter wereld. Hiermee is verdere bewijsvoering niet nodig: recht wordt snel een sexy product waarvan zelfs Staten vinden dat zij het moeten vermarkten.

Drie vragen In het navolgende zal ik aan drie vragen over deze rechtsmarkt aandacht besteden. In de eerste plaats is er de theoretische en ambitieuze vraag naar wat de opkomst van een rechtsmarkt betekent voor de verhouding tussen de Staat, zijn grondgebied, zijn burgers en het recht. Een tweede vraag is de normatieve vraag hoe de rechtsmarkt te waarderen: is dit een goede ontwikkeling? In geval van een ontkennend antwoord is het aan wetgever of rechter om er een einde aan te maken. Indien de rechtsmarkt aan de andere kant positief moet worden gewaardeerd, dan is de vervolgvraag hoe deze te

\footnotetext{
'Zie vooral Erin A. O'Hara en Larry E. Ribstein, The Law Market, Oxford 2009 en Horst Eidenmüller, Recht als Produkt, JuristenZeitung 64 (2009), p. 641 v.

${ }^{2}$ Beschikbaar via <http://www.lawsociety.org.uk>

${ }^{3}$ Beschikbaar via <http://www.lawmadeingermany.de>
} 
bevorderen. Dit is dan ook de derde vraag. Gelet op de beperkte tijd die voor het uitspreken van deze rede beschikbaar is, kunnen deze vragen hier niet uitgebreid worden beantwoord. Dat zal wel geschieden in de uitgebreide Engelstalige versie die later dit jaar verschijnt.

\section{Staat, grondgebied,}

burgers en recht De eerste vraag is die naar de verhouding tussen de Staat, zijn grondgebied, zijn burgers en het recht. Toen ik in de jaren tachtig rechten studeerde werd mij verteld dat deze grootheden onlosmakelijk met elkaar zijn verbonden. Onderwezen werd dat recht tot stand komt in een democratisch proces en daarom bindend is voor de burgers die bij dat proces betrokken zijn. De achtergrond van die opvatting wordt gevormd door het rechtsfilosofisch gedachtegoed van het maatschappelijk verdrag: Staat en burgers hebben een (hypothetisch) contract met elkaar gesloten. Minstens even belangrijk in deze opvatting is dat de Staat een grondgebied heeft waarop het macht kan uitoefenen. Door één auteur wordt deze onlosmakelijke band omschreven als de heilige drie-eenheid van soevereiniteit, burgerschap en nationale identiteit. ${ }^{4}$

Voor juristen die met deze opvatting zijn opgegroeid is het moeilijk om hier op een andere manier tegen aan te kijken. En toch is het een relatief recente uitvinding om burgers aan een grondgebied te koppelen en dat grondgebied vervolgens aan een Staat. Dit is in essentie het gevolg van de Vrede van Münster van 1648 en het proces van vorming van natiestaten dat daarop volgde. In de Middeleeuwen nam de burger zijn eigen recht mee wanneer hij op reis ging naar verre landen. Recht was in die tijd primair gebonden aan personen, niet aan plaatsen. Het was met andere woorden de status van de persoon die bepaalde welk recht op hem van toepassing was, een situatie die terecht als hoogst onwenselijk werd beschouwd omdat personen vaak niet in staat waren om zich van hun status te bevrijden. De afgelopen driehonderd jaar hebben wij mensen daarom georganiseerd naar het grondgebied waarop zij leven of naar de nationaliteit die zij hebben. Maar ook deze wijze van organisatie lijkt niet langer adequaat. De thans tot ontwikkeling komende rechtsmarkt kan het begin zijn van een nieuw tijdperk waarin recht wederom verbonden is aan een persoon, dit keer echter niet omdat die een bepaalde status heeft, maar omdat die een keuze heeft gemaakt. Indien individuen daadwerkelijk in staat zijn om op bepaalde terreinen recht van andere Staten te kiezen, betekent dit dat het gezag van de Staat over zijn 'eigen' burgers weglekt naar andere Staten. Landen treden hiermee met elkaar in concurrentie om contractspartijen, geliefden en - zelfs - sporters aan zich

\footnotetext{
4 Veit Bader, Complex Citizenship and Legitimacy in Compound Polities: The EU as Example, Eurosphere working paper series 2008-05, p. 2.
} 
te binden. De consequentie daarvan is dat in Nederland niet langer één Nederlands recht geldt. Burgers worden daarentegen geregeerd door verschillende rechtsstelsels, afhankelijk van de keuzes die zij hebben gemaakt. In andere landen is dat niet anders. Dit moet mijns inziens leiden tot een grondige herbezinning op de verhouding tussen nationale Staat en burger. Het is slechts één voorbeeld van waar constitutioneel recht (dat de grenzen van de individuele autonomie ten opzichte van de Staat aangeeft) en privaatrecht (dat aan die autonomie handen en voeten geeft) elkaar ontmoeten.

\section{Rechtstoerisme goed}

voor burger en Staat De tweede vraag is hoe de rechtsmarkt te waarderen: kan het type rechtstoerisme dat hiervoor is beschreven als positief worden beschouwd? Op het eerste gezicht bent $u$ wellicht geneigd te denken dat wij hier met een weinig aanlokkelijk fenomeen te maken hebben: burgers die op een bepaald terrein de oplossing van hun eigen Staat inruilen voor een andere om zo hun voorkeuren bevredigd te zien, lijkt niet iets dat moet worden aangemoedigd. Deze op zichzelf begrijpelijke reactie is mijns inziens echter de volstrekt verkeerde. Daartoe dienen wij ons eerst te realiseren dat de rechtsmarkt bestaat binnen het huidige juridische kader: er is niets illegaals aan. Wel is het zo dat Staten in beginsel kunnen bepalen dat een keuze van hun burgers voor (een deel van) een buitenlands rechtsstelsel niet wordt erkend. Zij waren immers in staat om te kiezen voor het parlement en moeten daarom hun eigen, democratisch gelegitimeerde, nationale recht aanvaarden.

Het zou mijns inziens echter volkomen verkeerd zijn indien nationale Staten op deze wijze reageren als hun burgers kiezen voor een ander rechtsstelsel. Dat zou immers betekenen dat de Staat de oplossing waartoe hij zelf komt als de enige juiste beschouwt. Zelfs wanneer een nationaal parlement na lange beraadslagingen tot een bepaalde uitkomst komt (vaak in de vorm van een compromis), zullen velen het daarmee nog altijd oneens zijn. Er bestaat immers niet langer één ideale maatschappelijke oplossing; in plaats daarvan zijn er verschillende opvattingen die met elkaar concurreren. Indien dit inderdaad het geval is, is het dan niet veel beter om - op bepaalde terreinen - de keuze aan de burgers te laten en hen in staat te stellen om te kiezen voor de oplossing van een andere Staat? De Amerikaan Charles Tiebout legde vijftig jaar geleden de basis voor de opvatting dat mensen niet alleen via een parlement, maar ook met hun voeten kunnen stemmen. Die gedachte heeft niets van haar betekenis verloren. Wel is zij moeilijk in overeenstemming te brengen met de eerder genoemde theorie van het maatschappelijk verdrag die de laatste eeuwen zo populair is geweest, van Hobbes, Locke en Rousseau in het verleden tot Rawls en Habermas in de huidige tijd. Maar in een tijdperk van internatio- 
nalisering is de gedachte van een hypothetisch contract tussen Staat en burgers, waarmee bovendien slechts één enkele uitkomst als de juiste wordt aanvaard, adequaat noch wenselijk.

Recent heeft ook econoom en filosoof Amartya Sen - hij stond in 1995 op deze plek in dit auditorium toen hij de Nexus-lezing gaf - nog eens bepleit dat er niet één beste keuze is voor iedereen. Een rechtstheorie moet daarentegen 'have something to say about the choices that are actually on offer.' ${ }^{5} \mathrm{Er}$ is niet één ideaal recht en we moeten er ook niet naar zoeken. Dat is een opvatting die mij bijzonder aanspreekt en die ik onlangs ook heb neergelegd in mijn boekje Omstreden rechtswetenschap ${ }^{6}$ : aan burgers de mogelijkheid bieden om voor een ander rechtsstelsel te opteren is een praktische manier om aan die rechtstheorie handen en voeten te geven.

Maar er is nog een andere reden waarom het verkeerd zou zijn om een keuze voor een buitenlands rechtsstelsel niet op uitgebreide schaal te erkennen. Dat is namelijk niet alleen gunstig voor individuele burgers, het is ook gunstig voor Staten. Ik heb al gewezen op de brochures die werden uitgegeven door de Engelse Law Society en de Duitse Minister van Justitie: zij hopen zo buitenlandse partijen naar het eigen land te trekken. Bij het homohuwelijk zien we iets soortgelijks. Zo zal Mexico-stad het homohuwelijk in maart 2010 toestaan en in een interview met een woordvoerder van het plaatselijke verkeersbureau heet het: 'Mexico City will become a centre, where people from all over the word will be able to come and have their wedding, and then spend their honeymoon here. We are already in talks with some travel agencies that are planning to offer package tours.' Zo kan een land sommige burgers verliezen aan een andere Staat, maar ook weer nieuwe burgers aantrekken.

Ook mijn antwoord op de tweede vraag is hiermee duidelijk: er zijn inderdaad goede redenen om personen in staat te stellen voor een andere jurisdictie (of een deel er van) te kiezen, zodat niet langer het recht van de plaats waar zij wonen of van hun nationaliteit toepasselijk is. Dit betekent uiteraard niet dat er geen grenzen zijn aan een rechtskeuze voor een buitenlands stelsel. Het is zelfs noodzakelijk dat Staten veel explicieter dan thans het geval is duidelijk maken waar deze grenzen precies liggen (juristen zouden zeggen: wanneer de keuze voor een ander stelsel wordt erkend). Maar bij het trekken van die grenzen moet veel vrijheid aan partijen worden gelaten. Dat is voor mij een kwestie van verdraagzaamheid. Indien een Staat die praktijk verbiedt of te zeer inperkt, zegt hij immers eigenlijk: 'alleen onze oplossing is aanvaardbaar.' Dat is een volstrekt verkeerde reactie.

\footnotetext{
${ }^{5}$ Amartya Sen, The Idea of Justice, Cambridge Mass. 2009, p. 106.

${ }^{6}$ Den Haag 2009.

${ }^{7}$ Zie <http://world-countries.net/archives/6107>
} 


\section{Hoe de rechtsmarkt}

serieus te nemen? Dit leidt mij tot de derde vraag: indien we enthousiast zijn over de rechtsmarkt, moeten we dan niet proberen om deze verder te ontwikkelen? Thans zijn de mogelijkheden nog beperkt om te kiezen voor een ander rechtsstelsel dan het stelsel dat in beginsel van toepassing is. En waar de mogelijkheid wel bestaat, is lang niet iedereen zich daar van bewust. Ik maak in dit verband nog enkele opmerkingen, eerst over privaatrecht en vervolgens over constitutioneel recht.

In het (internationaal) privaatrecht wordt een onderscheid gemaakt tussen een rechtskeuze die kan plaatsvinden zonder daarvoor te hoeven reizen (zoals in grote delen van het contracten- en ondernemingsrecht) en rechtskeuze waarbij fysieke verplaatsing naar de gewenste jurisdictie wel nodig is (zoals in delen van het familierecht). Een andere onderscheiding is die tussen puur nationale en internationale verhoudingen. In de laatste is rechtskeuze vaak wel mogelijk, in de eerste niet. Twee Nederlandse contractspartijen kunnen in beginsel niet kiezen voor Engels recht indien hun verhouding niet op zijn minst enig internationaal aspect heeft. Deze beide onderscheidingen kunnen weliswaar historisch worden verklaard, maar zij zijn in de wereld van vandaag steeds minder relevant. Het zijn overblijfselen uit een tijd waarin iemands fysieke aanwezigheid op een grondgebied de belangrijkste reden was voor de toepasselijkheid van een rechtssysteem. Maar vandaag de dag kunnen mensen gemakkelijk reizen. En als ze dat niet doen, biedt internet uitgebreide mogelijkheden om kosteloos met buitenlandse partijen in contact te treden. Hiermee wordt aanknoping bij nationaliteit of woonplaats steeds minder belangrijk en wie die aanknopingsfactoren wel gebruikt komt tot arbitraire uitkomsten omdat het vaak slechts toeval is waar partijen zich bevonden op het moment dat ze de overeenkomst sloten of huwden.

Ik pleit er daarom voor om rechtskeuze in meer gevallen mogelijk te maken dan thans het geval is. Zo is er geen goede reden om rechtskeuze in het contractenrecht te beperken tot enkel internationale verhoudingen. Twee Nederlandse contractpartijen in Tilburg zouden in staat moeten zijn om te kiezen voor bijvoorbeeld Duits of Italiaans recht. Evenmin is er in het huwelijksrecht een goede reden om een eis van woonplaats of nationaliteit te stellen. Twee Franse burgers die hier niet wonen moeten in staat zijn om in Amsterdam te huwen - net zoals twee Nederlanders naar Canada of Venetië kunnen gaan. Uiteraard betekent dit niet dat rechtstoerisme onbeperkt mogelijk is. Elke Staat moet hier eigen grenzen aan kunnen stellen, zij het dat - zoals al gezegd - ik vind dat die grenzen ruim moeten worden getrokken.

Vervolgens is er de vraag hoe constitutioneel recht wordt beïnvloed door de opkomende rechtsmarkt. Het eenvoudige (maar ook treffende) antwoord is om te zeggen dat dit op vele verschillende manieren het geval is. Vandaag beperk ik mij tot slechts één 
aspect: de vraag naar staatsburgerschap. De voorbeelden van Igor de Camargo en Bart Veldkamp laten zien dat burgers de noodzaak kunnen voelen om voor een andere nationaliteit te kiezen voor één specifiek aspect van hun leven. Beide voorbeelden mogen banaal lijken, maar ze verschaffen ons een belangrijk inzicht: personen kunnen zich beknot voelen wanneer zij slechts één nationaliteit hebben. Anders gezegd: voorkeuren van individuen verschillen soms te zeer om door slechts één Staat te worden bevredigd. Bij de vorming van de natiestaat in de achttiende en negentiende eeuw werd mensen verteld dat zij slechts burger waren van één Staat en aan die Staat loyaal moesten zijn. Vandaag de dag zijn preferenties van burgers duidelijk anders. Niet alleen kan men zich tegelijkertijd verbonden voelen met verschillende landen, ieders identiteit wordt tegenwoordig ook gevormd door elementen die daarvan onafhankelijk zijn. Amartya Sen zegt dat zo: 'we identify with people of the same religion, language group, race, gender, political beliefs, profession. $^{.8}$

Als we dit inzicht serieus nemen, kan het dan zijn dat, net zoals individuen kunnen kiezen voor een ander privaatrechtstelsel voor een bepaald aspect van wat zij doen, zij ook kunnen kiezen voor een Constitutie van een ander volk voor een ander aspect (zoals deelname aan een sporttoernooi)? Om het licht provocerend uit te drukken: kan ook een Grondwet een product zijn? Naar geldend recht moet het antwoord ontkennend luiden: vormen van gefragmenteerd burgerschap zijn nog uiterst beperkt. Voor academici is de vraag echter niet zozeer of gefragmenteerd burgerschap vandaag de dag bestaat, maar of het zou moeten bestaan. Hier kan worden voortgebouwd op het werk van de Zwitserse politicoloog Bruno Frey. ${ }^{9}$ Frey bepleit dat burgerschap inderdaad iets kan zijn waar burgers zelf voor kiezen door middel van contracten met een Staat of een andere entiteit met een publieke functie. Dit zou in zijn visie kunnen leiden tot vormen van burgerschap die tijdelijk (voor een aantal jaren), meervoudig (twee of meer nationaliteiten), gedeeltelijk (alleen voor bepaalde aspecten) en zelfs niet-nationaal (zoals het burgerschap van Catalonië, de Europese Unie en voor Frey zelfs van organisaties als Het Rode Kruis of een multinationaal bedrijf) zijn. Dit zou de politieke betrokkenheid van individuen bij de instituties waar ze deel van uitmaken aanzienlijk kunnen verhogen. Het enkel hypothetische maatschappelijk contract tussen de burgers en de Staat voor (bijna) alles wat de Staat doet zou zo deels plaatsmaken voor de werkelijke instemming van burgers voor die sectoren waar deze zelf voor een ander regime kiezen.

\footnotetext{
${ }^{8}$ Sen, The Idea of Justice, o.c., p. 129.

${ }^{9}$ Bijvoorbeeld in Bruno S. Frey en Reiner Eichenberger, The New Democratic Federalism for Europe, Northampton 1999.
} 
Dit alles mag voor sommigen onder $u$ revolutionair klinken, maar dat komt slechts omdat we gewend zijn aan het organiseren van de maatschappij langs de lijnen van de natiestaat. Dat is een uitvinding van slechts enkele honderden jaren oud die thans opnieuw moet worden doordacht. Ook hier ligt een veelheid aan mogelijkheden voor inspirerend onderzoek. Dit onderzoek vindt noodzakelijkerwijs plaats op het grensvlak van disciplines. Ik noemde al eerder privaatrecht, constitutioneel recht en rechtsfilosofie, maar grondig onderzoek naar de consequenties van toenemende internationalisering van recht betrekt daar nog meer rechtsgebieden bij. Om slechts één voorbeeld te noemen: indien burgerschap - zoals Bruno Frey voorstelt - inderdaad kan worden gebaseerd op overeenkomsten tussen burgers en Staten zou dit ook het belastingrecht grondig beïnvloeden. Belastingheffing kan in dat geval niet langer primair worden gebaseerd op nationaliteit of woonplaats, maar zal andere aanknopingspunten moeten vinden. Bij het vormgeven van een nieuw juridisch raamwerk voor een Europese (of zelfs kosmopolitische) samenleving kan dus niet langer worden vastgehouden aan de traditionele onderscheidingen tussen juridische disciplines. Er moet iets nieuws worden opgebouwd en dat kan alleen door bestaande grenzen te verleggen. Johnny Cash zong het al: 'A cake's no good if you don't mix the batter and bake it.'

Synopsis $\mathrm{k}$ ben thans in staat om enkele voorlopige conclusies te trekken (de definitieve komen beschikbaar in de uitgebreide Engelstalige versie van deze oratie). Ik sprak vandaag over één specifieke wijze van internationalisering van recht: de opkomende rechtsmarkt. Ik heb getracht om aan te tonen dat deze rechtsmarkt niet als negatief moet worden gewaardeerd. Integendeel: op die terreinen waar een rechtsmarkt bestaat, kan worden gedacht in termen van alternatieve oplossingen waarbij het aan de burger is om te kiezen voor de oplossing die hij het beste vindt. Voor academici liggen hier prachtige mogelijkheden voor fundamenteel en inspirerend onderzoek. Dat type onderzoek wordt gedaan door de onderzoekers van TICOM, het Tilburg Institute of Comparative and Transnational Law. Dit heeft niet alleen betrekking op de rechtsmarkt, maar ook op andere aspecten van Europees constitutioneel recht, Europees privaatrecht en Europeanisering en globalisering van recht in het algemeen. Daarbij zijn we gelukkig net zo min gebonden aan de grenzen tussen Staten als aan die tussen disciplines. 
Ten slotte Mijnheer de Rector Magnificus, Dames en heren. Aan het einde van deze kleine reis rond de wereld en voorbij het recht van de nationale Staat wil ik graag verschillende personen bedanken. Ik hoop dat $u$ het mij niet kwalijk neemt als ik daar enige tijd voor neem: rechtswetenschap is voor mij een sociale activiteit en dus onmogelijk zonder permanente interactie met collega's.

Ik dank in de eerste plaats alle aanwezigen: uw komst naar deze ceremonie doet mij veel.

Vervolgens wil ik graag mijn dank betuigen aan het College van Bestuur van de Universiteit van Tilburg voor mijn benoeming op de leerstoel Europees privaatrecht en rechtsvergelijking. Ik ben mij er van bewust dat dit een bijzondere leerstoel is en ik voel mij bevoorrecht dat ik deze leerstoel mag bezetten. Dit was niet mogelijk geweest zonder de grote inzet van enkelen. Ik noem Philip Eijlander, voormalig decaan van de Faculteit der Rechtsgeleerdheid en thans hier aanwezig in zijn hoedanigheid van Rector. Ik dank ook Jan Vranken: zonder zijn vasthoudendheid had ik hier vandaag niet gestaan. Zijn wetenschappelijk werk en zijn visie op het wezen van de universiteit zijn voor mij altijd een bron van inspiratie geweest. Ten slotte dank ik Randall Lesaffer, Decaan van - wat thans heet - de Faculteit Rechtswetenschappen, voor zijn steun.

Waarde Schoordijk, beste Herman. Je bent het oudste lid van de Tilburgse Faculteit. Ik beschouw het als een eer dat je hier vandaag aanwezig bent. De eerste keer dat ik met je kennis maakte, was ik student in Leiden. De kennismaking vond plaats door lezing van je geschriften. Die leerden mij iets nieuws, namelijk dat recht debat is en dat men daarover moet schrijven 'not to defend, but to be accused.' Het is een manier van wetenschapsbeoefening die mij bijzonder aanspreekt en die ik dagelijks in de praktijk probeer te brengen.

Ik sta hier in de toga van de Universiteit Maastricht. Het is de toga waarin ik tien jaar geleden mijn eerste inaugurele rede hield. De traditie aan Nederlandse universiteiten is dat men de toga houdt van de eerste universiteit waar men tot hoogleraar werd benoemd. Ik geef niet veel om tradities, maar ik ben er wel trots op om de Maastrichtse toga te blijven dragen. Ik heb gedurende twaalf jaar met groot plezier in Maastricht gewerkt en ik denk vaak terug aan de goede sfeer die er heerst, aan het geringe belang dat er wordt gehecht aan grenzen tussen vakgebieden en aan de ver voortgeschreden internationalisering van studenten en staf. Een dergelijke Faculteit verlaten valt een mens niet gemakkelijk. Het is ook daarom dat ik grote waarde hecht aan de goede contacten die ik nog altijd heb met mijn Maastrichtse collega's en met de Onderzoeksschool lus Commune. 
Waarde leden van TICOM. Nu anderhalf jaar geleden richtten wij het Tilburg Institute of Comparative and Transnational Law op. Zoals jullie weten zie ik TICOM graag als een schip dat de zeeën der wetenschap bevaart op zoek naar fundamentele kennis. Een onderzoeksgroep wordt mijns inziens niet primair gevormd door wat zijn leiders doen, maar door de activiteiten van de overige leden. Gelukkig zijn we dan ook uitgevaren met zulke enthousiaste collega's als - in alfabetische volgorde - Esther, Gary, José, Lars, Maartje, Mark, Nikos en Viorelia. Ik noem ook onze invited fellows en adviesraad en zeg hoe verheugd ik ben om ook hen aan boord te hebben.

Waarde Claes, beste Monica. Jij bent mijn collega proximus binnen TICOM. Wij zijn dit academisch avontuur samen gestart. Onze samenwerking in de afgelopen twee jaar heeft mij doen realiseren dat je een van de beste collega's bent die men zich kan indenken. Buitenstaanders vinden het soms vreemd om Europees privaatrecht en Europees publiekrecht verenigd te zien in één instituut. Wij weten beter. Het onderscheid tussen publiek en privaat is weinig zinvol zodra recht op internationale wijze wordt beoefend. Om samen met jou te onderzoeken waar de nieuwe grenzen liggen is een voorrecht.

Waarde collega's van de Faculteit Rechtswetenschappen. Het is tijdens deze rede al overduidelijk geworden dat ik niet houd van scheidingen tussen rechtsgebieden. Evenmin houd ik van strikte schotten tussen vakgroepen. Ik vind dat wij één Faculteit zijn en ik hoop dat we in de toekomst meer kunnen samenwerken. Vandaag wil ik twee groepen noemen met wie die samenwerking al gestalte heeft gekregen. In de eerste plaats zijn dat de leden van de Onderzoeksgroep Methodologie van recht en rechtswetenschap. Het is een vreugde om lid te zijn van deze groep, juist omdat we niet altijd dezelfde opvatting hebben over het doel van juridisch onderzoek of het belang van een expliciet geformuleerde onderzoeksvraag. In de tweede plaats noem ik mijn naaste collega's op de vijfde verdieping van het Montesquieu-gebouw, collega's van de vakgroep Internationaal en Europees Recht en van het Tilburg Law and Economics Center. Wij werken samen in harmonie in plaats van elkaar te beconcurreren. Dat is volgens mij een noodzakelijke voorwaarde voor een stimulerend academisch klimaat. Ik dank in het bijzonder Willem van Genugten voor het welkom dat hij me gaf.

Beste studenten. Het doet me buitengewoon veel plezier dat enkelen van jullie hier vandaag aanwezig zijn. De universiteit is er in de eerste plaats voor jullie. Afgelopen week begonnen wederom de colleges in de vakken European Private Law en The Common Law of Europe. Zoals jullie nu reeds hebben ervaren is mijn onderwijsmodel er een waarin we samen op zoek zijn naar antwoorden op de vele vragen die Europeanisering van recht oproept. Jullie bijdrage aan die speurtocht naar kennis is even belangrijk als de mijne. 
Lieve familie. De bijna laatste woorden zijn voor jullie. Helaas zijn mijn beide ouders niet langer fysiek in staat om te reizen, maar het doet me enorm veel plezier dat hier vandaag wel aanwezig zijn mijn zwager Herman met Ineke, nicht Marjolein en neef Bart, als ook mijn schoonvader, schoonzus Roelien en nichtje Fenna.

Liefste Christa. Het allerlaatste woord is voor jou. Zonder enig rechtstoerisme zouden wij elkaar niet hebben ontmoet. Misschien verklaart dát mijn enthousiasme voor het onderwerp van vandaag. Jij bent immers de allerbelangrijkste in mijn leven. Als het grootste geluk beschouw ik dat er elke dag momenten zijn waarop ik dat tegen je kan zeggen.

\section{Ik heb gezegd}





\section{Colophon}

vormgeving

Beelenkamp Ontwerpers, Tilburg

fotografie omslag

Ton Toemen

druk

PrismaPrint, Tilburg 

Jan.M. Smits is hoogleraar Europees privaatrecht en rechtsvergelijking aan de Universiteit van Tilburg en wetenschappelijk directeur van het Tilburg Institute of Comparative and Transnational Law (TICOM). Van 1999 tot 2008 was hij hoogleraar Europees privaatrecht aan de Universiteit Maastricht. Hij is tevens gasthoogleraar

Comparative Legal Studies aan de Universiteit van Helsinki en was eerder gasthoogleraar

aan onder meer de universiteiten van Leuven en Luik en aan de Dickinson School of Law. Zie voor meer informatie over Smits en zijn wetenschappelijk werk

<http://www.jansmits.eu>

Een uitgebreide wetenschappelijke Engelstalige versie van deze rede verschijnt in 2010

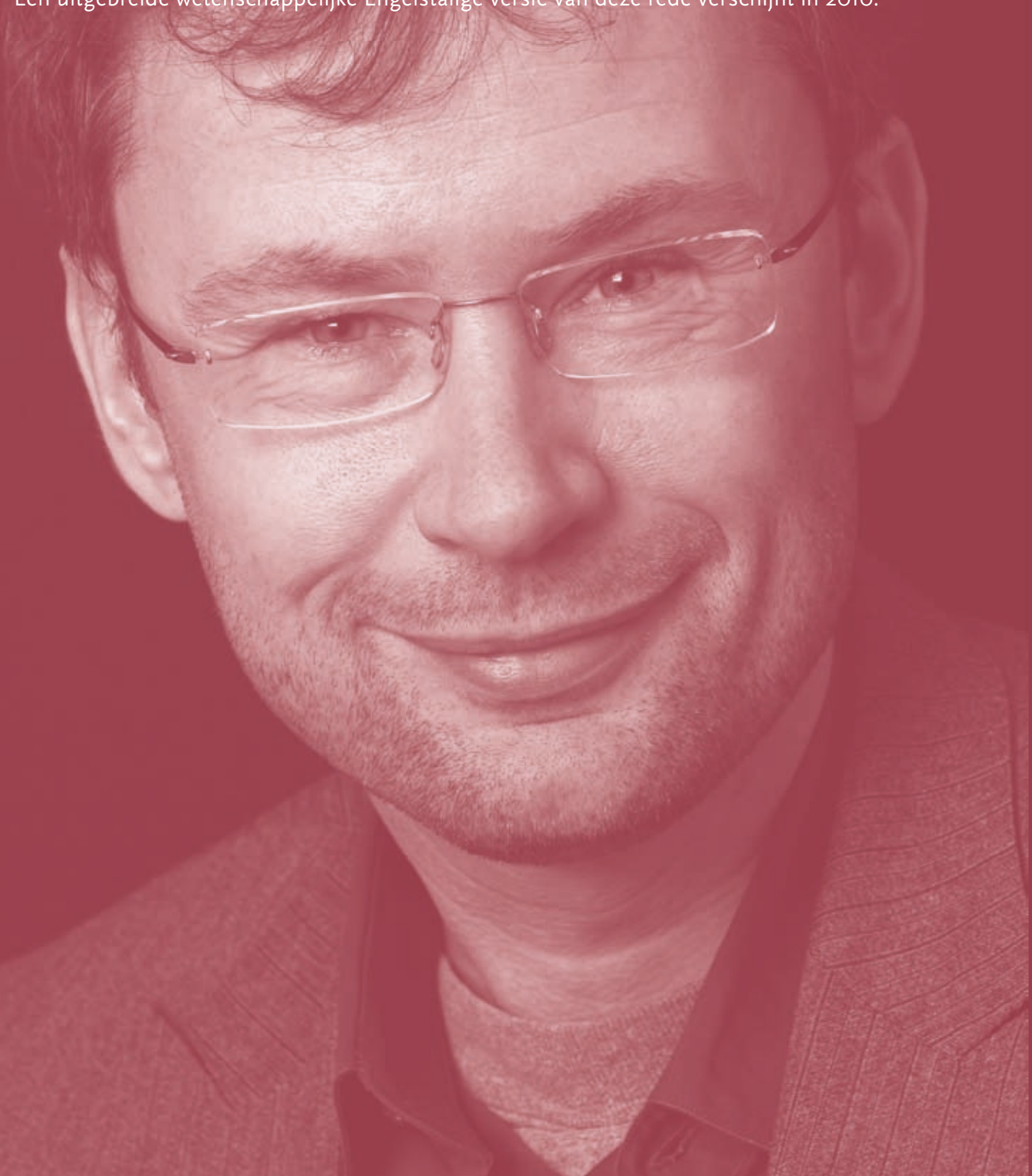

\section{Colophon}

vormgeving

Beelenkamp Ontwerpers, Tilburg

fotografie omslag

Ton Toemen

druk

PrismaPrint, Tilburg 